\title{
PREFERENSI HAMA Thrips sp. (Thysanoptera : Thripidae) TERHADAP PERANGKAP BERWARNA PADA TANAMAN CABAI
}

\section{PREFERENCES OF Thrips sp. (Thysanoptera: Thripidae) TO COLOR STICKY TRAP ON CHILLI CROPS}

\section{Caroulus S. Rante dan Guntur S.J. Manengkey*)}

")Jurusan Hama dan Penyakit Tumbuhan, Fakultas Pertanian Unsrat, Manado

lolurante@gmail.com

\begin{abstract}
The purpose of this research is to know the interest of Thrips sp. on various colored traps. This research has been conducted on farmers' land in Kakaskasen II Village, Tomohon City. The study used Randomized Block Design (RBD) with the following treatment: (A) pink trap; (B) yellow trap; (C) blue trap; (D) green trap and (E) white trap. Each treatment was replication three times. The results showed that Thrips sp. more interested in yellow traps than green, blue, white and pink traps. Average population of Thrips sp. fluctuates at first to seventh observations. The highest population was found in the yellow trap, the second observation was 134.67 and the fifth observation was 118.33 .
\end{abstract}

Keywords : Thrips sp., Thysanoptera, Thripidae, color sticky trap

\begin{abstract}
ABSTRAK
Tujuan penelitian adalah untuk mengetahui ketertarikan dari hama Thrips sp. pada berbagai perangkap berwarna. Penelitian ini telah dilaksanakan pada lahan petani di Desa Kakaskasen II, Kota Tomohon. Penelitian menggunakan Rancangan Acak Kelompok (RAK) dengan perlakuan sebagai berikut : (A) Perangkap berwarna merah muda; (B) Perangkap berwarna kuning; (C) Perangkap berwarna biru; (D) Perangkap berwarna hijau dan (E) Perangkap berwarna putih. Masing-masing perlakuan diulang tiga kali. Hasil penelitian menunjukkan bahwa hama Thrips sp. lebih tertarik pada perangkap berwarna kuning dibandingkan dengan perangkap warna hijau, biru, putih dan merah muda. Rataan populasi Thrips sp. berfluktuasi pada pengamatan pertama sampai ketujuh. Populasi tertinggi dijumpai pada perangkap berwarna kuning yakni pada pengamatan kedua (134,67 ekor) dan pengamatan kelima (118,33 ekor).

Kata kunci : Thrips sp., Thysanoptera, Thripidae, perangkap berwarna
\end{abstract}




\section{PENDAHULUAN}

Cabai merah (Capsicum annum L.) merupakan salah satu jenis sayuran penting yang bernilai ekonomis tinggi dan cocok untuk dikembangkan di daerah tropika seperti di Indonesia. Cabai sebagian besar digunakan untuk konsumsi rumah tangga dan sebagiannya untuk ekspor dalam bentuk kering, saus, tepung dan lainnya (Anonim, 2008). Khusus di Propinsi Sulawesi Utara, cabai merah termasuk salah satu komoditi tanaman sayuran unggulan karena kebutuhan masyarakat Sulawesi Utara akan cabai sangat tinggi. Komoditi tersebut banyak diusahakan di lahan kering baik dataran tinggi maupun dataran rendah.

Produktivitas tanaman cabai dapat berkurang disebabkan oleh gangguan berbagai Organisme Pengganggu Tanaman (OPT), salah satunya yaitu serangga hama dari Ordo Thysanoptera, famili Thripidae atau yang lebih dikenal dengan nama Thrips sp. Serangga ini banyak dikenal sebagai hama pada berbagai komoditas pertanian dan bersifat polifag. Kerusakan akibat serangannya sangat bervariasi, dari kerusakan ringan sampai kerusakan berat hingga dapat mengakibatkan kehilangan hasil panen yang sangat serius (Prabaningrum dan Suhardjono, 2007). Lebih lanjut dikemukakan bahwa kerusakan yang ditimbulkan oleh hama Thrips sp. pada tanaman cabai berkisar dari $12,00-74,00 \%$, bahkan pada tanaman bawang putih kerusakan dapat mencapai $80,00 \%$.

Kerusakan tanaman yang diakibatkan oleh hama Thrips sp. akan menyebabkan perubahan warna dan bentuk serta ukuran daun tanaman cabai. Hama Thrips sp. merusak tunas, daun, dan bunga dengan menusuk jaringan tanaman dan mengisap cairan tanaman (Kalshoven, 1981). Kotoran (faces) dari hama ini merupakan media pertumbuhan bagi cendawan sehingga dapat mengganggu proses fotosistesis dari tanaman. Hama Thrips sp. juga dapat berfungsi sebagai vektor penyakit tanaman. Banyak jenis virus yang menginfeksi tanaman dibawa oleh Thrips sp. Virus Tomato Spotted Wilt Virus (TSWV) menyebabkan kehilangan hasil tomat $\$ 1,4$ billion selama 10 tahun di Georgia (Riley, at. al., 2011). Hama Thrips sp. sebagai penyebar penyakit virus keriting pada daun cabai, dapat menyebabkan kerugian hasil 30,00$50,00 \%$ (Talekar, 1991). Lebih lanjut dilaporkan oleh Ratulangi, dkk. (2014), pertanaman cabai di daerah Kakaskasen, Kota Tomohon, Propinsi Sulawesi Utara terserang oleh hama Thrips sp. dan virus, persentase serangannya mencapai $100 \%$. Akibat serangan hama Thrips sp. dan virus tersebut, produksi cabai keriting pada sejumlah petak penanaman menjadi sangat rendah, bahkan sejumlah petani sudah membiarkan tanaman tersebut untuk tidak dipanen lagi.

Kelangsungan hidup Thrips sp. sangat dipengaruhi oleh faktor abiotik. Hama Thrips sp. dapat berpindah tempat dari satu bagian tanaman ke bagian tanaman lain dengan cara berlari, meloncat, atau terbang. Kemampuan terbang dari hama Thrips sp. sangat lemah, maka untuk perpindahan dari satu tanaman ke tanaman lain sangat dipengaruhi oleh faktor luar seperti angin. Suhu dan curah hujan merupakan faktor iklim yang sangat mempengaruhi populasi Thrips sp. (Lewis, 1973). Pada daerah dengan kelembaban yang relatif rendah dan suhu relatif tinggi perkembangbiakan Thrips sp. dari pupa menjadi imago menjadi lebih cepat. Pada musim kemarau populasi serangga ini lebih tinggi dan populasi akan berkurang apabila terjadi hujan lebat.

Sampai saat ini upaya pengendalian yang dilakukan oleh petani terhadap hama Thrips sp. yakni dengan menggunakan insektisida Profenofos $500 \mathrm{~g} / \mathrm{l}$ dan, Deltametrin $25 \mathrm{~g} / \mathrm{l}$. Upaya pengendalian yang dilakukan oleh petani kurang efektif karena berdasarkan pengamatan di lapang, hama Thrips sp. biasanya bersembunyi pada bagian daun atau pada bunga yang belum membuka sempurna. Selain itu, penggunaan insektisida berbahan aktif kimiawi yang secara terus menerus dapat menimbulkan efek resistensi dan resurgensi terhadap serangga hama dan matinya berbagai musuh alami serta dapat mengakibatkan pencemaran lingkungan yang berdampak buruk terhadap kesehatan manusia (Untung, 1993).

Agar tindakan pengendalian suatu jenis serangga hama dapat efektif dan tepat sasaran serta meminimalisir dampak buruk dari penggunaan insektisida kiamawi maka perlu terlebih dahulu dilakukan pemantauan tentang kepadatan populasi 
serangga hama tersebut. Salah satu cara melakukan pemantauan kepadatan populasi adalah memanfaatkan sifat-sifat dari serangga hama tersebut, salah satunya yakni ketertarikan pada warna untuk berkumpul dan hinggap pada suatu perangkap. Hasil penelitian yang dilakukan oleh Walker (1974) bahwa anggota dari ordo Thysanoptera memiliki ketertarikan terhadap warna perangkap namun sulit diprediksi. Lebih lanjut Sihombing (2004) mengemukakan bahwa percobaan yang dilakukan di rumah kaca, hama Thrips sp. tertarik pada perangkap warna kuning. Menurut Arno, et. al. (1995), hama Thrips sp. tertarik pada warna biru, sedangkan Huang (1989), Thrips sp. tertarik pada warna putih.

Penelitian tentang preferensi hama Thrips sp. terhadap berbagai perangkap berwarna pada tanaman cabai belum banyak dilakukan dan dipublikasikan. Oleh karenanya, hasil penelitian ini diharapkan dapat memberikan informasi jenis warna perangkap yang efektif digunakan sebagai perangkap bagi hama Thrips sp. yang selanjutnya digunakan dan disebarkan ke petani sebagai metode pengendalian hama Thrips sp. pada tanaman cabai.

\section{METODE PENELITIAN}

Penelitian dilaksanakan di Kelurahan Kakaskasen II, Kecamatan Tomohon Utara selama kurang lebih delapan bulan yang dimulai pada bulan Maret sampai dengan bulan Oktober 2015.

Bahan dan alat yang digunakan dalam penelitian ini adalah: benih cabai keriting varietas Flash, pupuk kandang, pupuk NPK, pupuk cair organik, insektisida, lem perekat, mulsa plastik, aquades.

Alat-alat yang digunakan adalah sekop, meteran, ajir bambu, tripleks berukuran $33,3 \mathrm{~cm} x$ $21,0 \mathrm{~cm}$, cet warna merah muda, kuning, biru, hijau dan putih, kuas, aspirator, hand counter, mikroskop, kamera dan alat tulis menulis.
Penelitian menggunakan Rancangan Acak Kelompok (RAK) dengan perlakuan sebagai berikut: (A) perangkap berwarna merah muda; (B) perangkap berwarna kuning; $(C)$ perangkap berwarna biru; (D) perangkap berwarna hijau dan (E) perangkap berwarna putih. Masing-masing perlakuan diulang tiga kali.

Perangkap terbuat dari papan tripleks dengan ukuran $33,0 \mathrm{~cm} \times 21,0 \mathrm{~cm}$. Tripleks tersebut ditempeli kertas berwarna sesuai perlakuan yakni warna merah muda, kuning, biru, hijau dan putih. Masing-masing perangkap berwarna tersebut dimasukkan dalam plastik transparan, kemudian plastik diberi perekat agar hama Thrips sp. dapat melengket. Perangkap berwarna diletakkan sesuai masing-masing perlakuan. Setiap perlakuan diulang tiga kali, sehingga jumlah bedengan sebanyak 15 bedengan. Setiap bedengan dipasang dua buah perangkap berwarna sesuai perlakuan, sehingga total perangkap yang dibutuhkan yakni sebanyak 30 buah. Tata letak dan model perangkap berwarna di lapangan dapat dilihat pada Gambar 1 dan 2.

\section{Pengamatan}

Pengamatan populasi hama Thrips sp. dilakukan seminggu sekali selama tujuh minggu berturut-turut, pada saat tanaman cabai memasuki masa berbunga. Setiap selesai pengamatan dilakukan pergantian plastik transparan yang telah diberi perekat. Hal-hal yang diamati adalah (i) gejala serangan hama Thrips sp. pada tanaman cabai, (ii) populasi serangga hama Thrips sp. pada masingmasing perangkap yang diukur melalui jumlah Thrips sp. yang terperangkap pada masing-masing perangkap berwarna.

\section{Analisis Data}

Data yang diperoleh dari hasil pengamatan dianalisis menggunakan sidik ragam. Apabila perlakuan menunjukkan pengaruh yang nyata, maka dilakukan uji lanjut Beda Nyata Jujur (BNJ) dengan tingkat kepercayaan 95\%. 


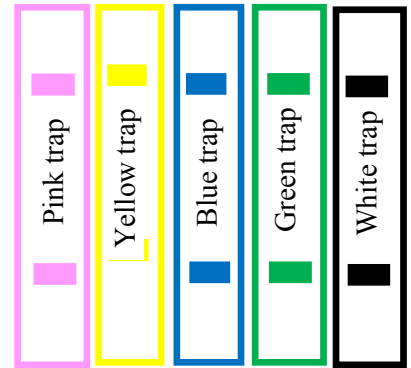

Kelompok 1
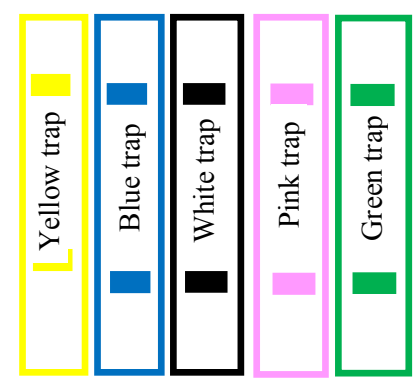
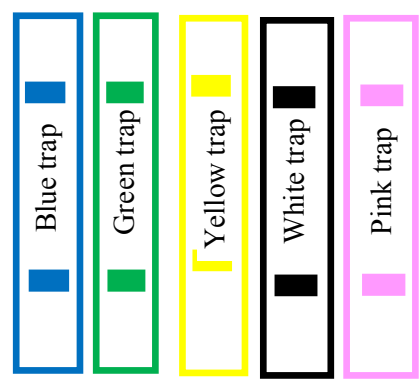

Kelompok 2

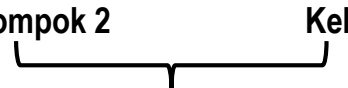

Kelompok 3

Gambar 1. Tata Letak Perangkap Berwarna di Lapangan

(Figure 1. Color Sticky Trap Layout in the Field)

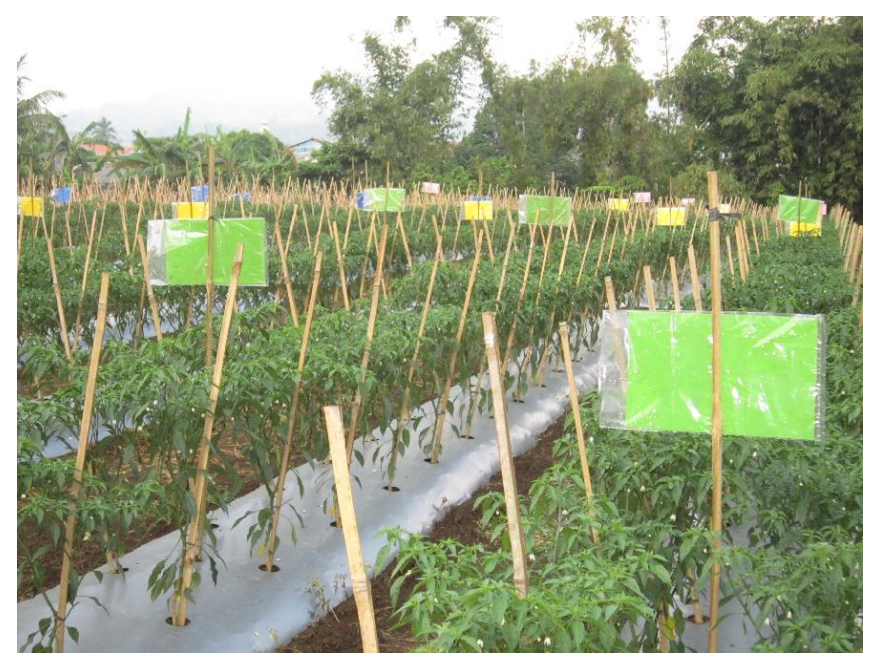

Gambar 2. Model Perangkap Berwarna di Lapangan

(Figure 2. Models of Color Sticky Trap in the Field)

\section{HASIL DAN PEMBAHASAN}

\section{Gejala Serangan Thrips sp.}

Hama Thrips sp. seringkali banyak dijumpai pada bagian-bagian tertentu dari tanaman cabai. Bagian tanaman cabai yang banyak ditemukan Thrips sp. yakni pada bagian permukaan bawah daun, bagian bunga dan bagian buah yang relatif masih muda. Gejala serangan oleh Thrips sp. pada bagian daun cabai yakni tampak daun menunjukkan berkeriput dan melengkung ke atas serta seringkali menunjukkan berwarna keperakan. Perubahan warna daun tersebut dikarenakan masuknya udara kedalam jaringan sel yang telah dihisap cairannya oleh hama Thrips sp. tersebut. Apabila bercak tersebut saling berdekatan dan akhirnya bersatu, maka seluruh daun akan memutih. Lama kelamaan warna bercak akan berubah menjadi coklat dan akhirnya daun akan mati.

\section{Populasi Thrips sp.}

Hasil pengamatan menunjukkan bahwa populasi Thrips sp. yang terperangkap pada kelima perlakuan warna perangkap sejak pengamatan pertama sampai pengamatan ketujuh sangat berfluktuasi. Hasil analisis sidik ragam rataan populasi Thrips sp. yang terperangkap pada kelima perlakuan warna perangkap sejak pengamatan pertama sampai pengamatan ketujuh menunjukkan pengaruh yang nyata. Rataan populasi Thrips sp. yang terperangkap pada kelima perlakuan warna ditunjukkan pada Tabel 1. 
Tabel 1. Rataan Populasi Hama Thrips sp. yang Terperangkap pada Kelima Warna Perangkap

(Table 1. Average Thrips sp. the Trapped on the Fifth Color Sticky Trap)

\begin{tabular}{lrrrrrrr}
\hline \multirow{2}{*}{ Perlakuan } & \multicolumn{7}{c}{ Populasi Hama Thrips sp. pada Pengamatan ke - } \\
\cline { 2 - 8 } & \multicolumn{1}{c}{ I } & \multicolumn{1}{c}{ II } & \multicolumn{1}{c}{ III } & \multicolumn{1}{c}{ IV } & \multicolumn{1}{c}{ V } & \multicolumn{1}{c}{ VI } & \multicolumn{1}{c}{ VII } \\
\hline Warna Hijau & $5.83 \mathrm{~b}$ & $2.33 \mathrm{a}$ & $3.83 \mathrm{a}$ & $19.17 \mathrm{~b}$ & $12.67 \mathrm{a}$ & $8.17 \mathrm{a}$ & $3.33 \mathrm{a}$ \\
Warna Kuning & $15.67 \mathrm{c}$ & $134.67 \mathrm{c}$ & $36.00 \mathrm{~b}$ & $93.00 \mathrm{c}$ & $118.33 \mathrm{c}$ & $73.87 \mathrm{~b}$ & $10.50 \mathrm{~b}$ \\
Warna Putih & $3.33 \mathrm{ab}$ & $2.67 \mathrm{a}$ & $4.33 \mathrm{a}$ & $9.00 \mathrm{ab}$ & $5.50 \mathrm{a}$ & $3.17 \mathrm{a}$ & $3.67 \mathrm{a}$ \\
Warna Biru & $1.00 \mathrm{a}$ & $1.83 \mathrm{a}$ & $2.13 \mathrm{a}$ & $6.83 \mathrm{a}$ & $4.67 \mathrm{a}$ & $5.67 \mathrm{a}$ & $3.83 \mathrm{a}$ \\
Warna Merah Muda & $1.00 \mathrm{a}$ & $2.0 \mathrm{a}$ & $2.33 \mathrm{a}$ & $8.83 \mathrm{ab}$ & $38.67 \mathrm{~b}$ & $11.00 \mathrm{a}$ & $4.67 \mathrm{a}$ \\
\hline
\end{tabular}

Dari Tabel 1 terlihat bahwa rataan populasi Thrips sp. yang terperangkap pada kelima warna perangkap berbeda-beda. Secara umum, rataan populasi hama Thrips sp. yang terbanyak terperangkap yakni pada perangkap berwarna kuning dibandingkan perangkap warna lainnya.

Populasi tertinggi dijumpai pada saat pengamatan kedua yakni 134,67 ekor dan terendah pada pengamatan ke tujuh sebesar 10,50 ekor. Kondisi ini menunjukkan bahwa perangkap berwarna kuning lebih disukai oleh hama Thrips sp. dibandingkan perangkap warna lainnya. Dilaporkan oleh Sihombing (2004) bahwa perangkap berwarna yang paling disukai oleh hama Thrips sp. adalah warna kuning, hal ini dibuktikan dengan banyaknya populasi hama Thrips sp. yang terperangkap pada warna kuning tersebut.

Brodsgaard (1993) mengemukakan pendapat yang lain bahwa hama Thrips sp. lebih tertarik pada perangkap warna biru dan putih. Pendapat ini tidak sesuai dengan hasil yang penelitian yang diperoleh dari lapang, bahwa populasi hama Thrips sp. yang terperangkap pada perlakuan warna biru dan putih sejak pengamatan pertama sampai ketujuh, populasinya rendah yang berarti kurang disenangi oleh hama Thrips sp. Demikian halnya pendapat yang dikemukakan oleh Huang (1989) dan Sridhar and Naik (2015) bahwa hama Thrips sp. lebih menyukai warna biru. Gharekhani, et. al. (2014) mengemukakan bahwa ketertarikan hama Thrips sp. pada suatu warna sangat tergantung pada panjang gelombang dari warna tersebut. Sridhar and Naik (2015), Thrips sp. Menunjukkan respon yang lebih besar pada perangkap berwarna biru dengan pantulan panjang gelombang $460 \mathrm{~nm}$. Namun kondisi lapangan yang merupakan hasil dari penelitian ini ditemukan bahwa populasi
Thrips sp. yang terperangkap pada perangkap warna biru lebih rendah dibandingkan dengan perangkap berwarna kuning.

Rataan populasi hama Thrips sp. yang terperangkap pada perangkap berwarna kuning lebih tinggi dibandingkan dengan populasi yang tertangkap pada perangkap berwarna lainnya. Kondisi ini sesuai dengan yang dilaporkan oleh Malik, et. al. (2012) bahwa Thrips sp. lebih tertarik pada warna kuning. Hasil penelitian ini membuktikan bahwa perangkap warna kuning dapat digunakan untuk mengurangi populasi hama Thrips sp. pada tanaman cabai sehingga penggunaan insektisida secara berlebihan secara tidak langsung dapat dikurangi.

\section{KESIMPULAN DAN SARAN}

\section{Kesimpulan}

Hama Thrips sp. lebih tertarik pada perangkap berwarna kuning dibandingkan dengan perangkap warna hijau, biru, putih dan merah muda. Rataan populasi Thrips sp. berfluktuasi pada pengamatan pertama sampai ketujuh. Populasi tertinggi dijumpai pada perangkap berwarna kuning yakni pada pengamatan kedua sebesar 134,67 ekor dan pengamatan kelima sebesar 118,33 ekor dan terendah pada pengamatan ketujuh yakni sebesar 10,50 ekor.

\section{Saran}

Perlu dilakukan penelitian lanjutan mengenai jenis-jenis musuh alami (parasitoid dan predator) yang dapat terperangkap oleh perangkap berwarna kuning, hijau, biru, putih dan merah muda. 


\section{UCAPAN TERIMA KASIH}

Disampaikan terima kasih yang sebesarbesarnya kepada Bapak Jeremias Nangka selaku petani cabai Kelurahan Kakaskasen Dua yang banyak membantu peneliti dan LPPM Univeritas Sam Ratulangi Manado yang telah membiayai pelaksanaan penelitian ini.

\section{DAFTAR PUSTAKA}

Anonim. 2008. Teknologi Budidaya Cabai Merah. Balai Besar Pengkajian dan Pengembangan Teknologi Pertanian. Badan Penelitian dan Pengembangan Pertanian. ISBN: 978-9791415-28-2.

Arno, J., J. Riudaves, E. Moriones, J. Arumbulu, A. Lavina and R. Gabara. 1995. Monitoring Western Flowers Thrips As a Tomato Spooted Wilt Virus Vector in Tomato. In Proc. International Conference on Thysanoptera. P. 1997-2000.

Broadsgaard, F.H. 1993. Coloured Sticky Traps for Thrips sp. (Thysanoptera: Thripidae) Monitoring on Glass-house Cucumbers. Bulletin of OILB. SROP, 16: 19.22.

Gharekhani, G.H., S. Ghorbansyahi, M. Saber, and M. Bagheri. 2014. Influence of the Colour and Height of Sticky Traps in att Raction of Thrips Tabaci (Lindeman) (Thysanoptera, Thripidae) and Predatory Thrips of Family Aeolothripidae on Garlic, Onion and Tomato Crops. Archives of Phytopathology and Plant Protection, 47(18): 2270-2275.

Huang, K.C. 1989. The Population Fluctuation and Trapping of Thrips palm in Waxgourd, Bull. Of the Taichung Distric. Agric Improvement Station. 25:35-41.
Kalshoven, L.G.E. 1981, Pest of Crops in Indonesia, P.T. Ichtiar Baru-Van Hoeve, Jakarta.

Lewis, T. 1973. Thrips: Their Biology, Economic, and Economic Importance. London: Academic Press.

Malik, M.I., R.D. Khuhro, K.H. Dhiloo, B. Zaman, and S.N. Khuhro. 2013. Response of Suckinginsect Complex to Various Colors of Sticky Traps in Okra Crop. Pakistan Journal of Entomology, 27(2): 181-186.

Prabaningrum, L dan Y.R. Suhardjono. 2007. Identifikasi Spesies Trips (Thysanoptera) pada Tanaman Paprika (Capsicum annum var. grossum) di Kabupaten Bandung, Jawa Barat. J. Hort. 17(3) : 270-276.

Ratulangi, M., Elisabet R.M. Meray, C.S. Rante, D. Kandowangko dan M.F. Dien. 2014. Study on the Effect of Plastic Row Tunnel on Population of Pests, Diseases and Production of Chili. Collaboration Sam Ratulangi University with USAID, IPM-IL and Clemson University. Research Report.

Riley, D.G., S.V. Joseph, R. Srinivasan and S. Diffie. 2011. Thrips Vectors of Tospoviruses. J. Integ. Pest Mngmt. 1(2): 2011.

Sihombing, D. 2004. Efektivitas Perangkap Berwarna dalam Pemantauan dan Pengendalian Hama Thrips Sedap Malam. Prosiding Seminar Nasional Florikultura. Bogor 4-5 Agustus 2004. Hal 427-431.

Sridhar, V and S.O. Naik. 2015. Efficacy of Colour Sticky Traps for Monitoring Chilli Thrips, Scirtothrips Dorsalis Hood (Thysanoptera: Thripidae) on Rose. 
Talekar, N.S. 1991. Thrips in Southeast Asia. Proc. Regional Consultation Workshop Bangkok, Thailand, 13 March 1991. AVRDC, Taiwan, ROC. p 61-67.

Untung, K. 1993. Pengatar Pengelolaan Hama Terpadu. Gadjah Mada University Press. 273 hal.
Walker, W.F. 1974. Respons of Selected Thysanoptera to Colored Surface. Environt. Entomol. 3:295-304. 